University of Nebraska - Lincoln

DigitalCommons@University of Nebraska - Lincoln

Biological Systems Engineering: Papers and

Publications

Biological Systems Engineering

2013

\title{
Network analysis of endogenous gene expression profiles after polyethyleneimine-mediated DNA delivery
}

Timothy M. Martin

University of Nebraska-Lincoln, timothy.michael.martin@gmail.com

Sarah A. Plautz

University of Nebraska-Lincoln, sarah.plautz@unl.edu

Angela K. Pannier

University of Nebraska-Lincoln, apannier2@unl.edu

Follow this and additional works at: https://digitalcommons.unl.edu/biosysengfacpub

Part of the Bioresource and Agricultural Engineering Commons, Environmental Engineering Commons, and the Other Civil and Environmental Engineering Commons

Martin, Timothy M.; Plautz, Sarah A.; and Pannier, Angela K., "Network analysis of endogenous gene expression profiles after polyethyleneimine-mediated DNA delivery" (2013). Biological Systems Engineering: Papers and Publications. 424.

https://digitalcommons.unl.edu/biosysengfacpub/424

This Article is brought to you for free and open access by the Biological Systems Engineering at DigitalCommons@University of Nebraska - Lincoln. It has been accepted for inclusion in Biological Systems Engineering: Papers and Publications by an authorized administrator of DigitalCommons@University of Nebraska Lincoln. 


\title{
Network analysis of endogenous gene expression profiles after polyethyleneimine-mediated DNA delivery
}

\author{
Timothy M. Martin, Sarah A. Plautz, and Angela K. Pannier ${ }^{*}$ \\ Department of Biological Systems Engineering, University of Nebraska-Lincoln, Lincoln, NE, USA
}

\begin{abstract}
Background-DNA delivery systems, which transport exogenous DNA to cells, have applications that include gene therapy, tissue engineering and medical devices. Although the cationic nonviral DNA carrier polyethyleneimine (PEI) has been widely studied, the molecular factors and pathways underlying PEI-mediated DNA transfer remain largely unknown, preventing the design of more efficient delivery systems.
\end{abstract}

Methods-HEK $293 \mathrm{~T}$ cells were treated with polyplexes formed with PEI and pEGFPLuc encoding for green fluorescent protein (GFP). Transfected cells expressing GFP were flowseparated from treated, untransfected cells. Gene expression profiles were obtained using Affymetrix HG-U133 2.0 microarrays and differentially expressed genes were identified using R/ Bioconductor. Gene network analysis using EGAN (exploratory gene association network) bioinformatics tools was then used to find interaction among genes and enriched gene ontology (GO) terms related to transfection. Genes identified by this method were perturbed using pharmacologic activators or inhibitors to assess their effect on DNA transfer.

Results-Microarray analysis comparing transfected cells to untransfected cells revealed 215 genes to be differentially expressed, with the majority enriched to GO processes including metabolism, response to stimulus, cell cycle, biological regulation and cellular component organization or biogenesis pathways. Gene network analysis revealed a coordinated induction of RAP1A, SCG5, PGAP1, ATF3 and NEB genes implicated in cell stress, cell cycle and cytoskeletal processes. Altering pathways with pharmacologic agents confirmed the potential role of RAPIA, SCG5 and ATF3 in transfection.

Conclusions-Microarray and gene network analyses of the sorted, transfected cell population can identify potential mediators of transfection, providing a basis for the design of improved delivery systems.

\section{Keywords}

gene profile; HEK 293 T; microarray; nonviral gene delivery; PEI

\footnotetext{
(C) 2013 John Wiley \& Sons, Ltd.

"Correspondence to: Angela K. Pannier, Biological Systems Engineering, 231 L.W. Chase Hall, Lincoln, NE 68583-0726, USA. apannier2@unl.edu.

Supporting information

Supporting information may be found in the online version of this article.
} 


\section{Introduction}

The design of efficient nonviral gene delivery systems offers potential uses in applications such as gene therapy, tissue engineering, regenerative medicine, and medical devices. Nonviral gene delivery involves the delivery of exogenous gene(s) to cells, typically facilitated by the electrostatic complexation of the gene as plasmid DNA with a nonviral vector such as the commonly used cationic polyethyleneimine (PEI) polymer [1-3]. However, the lack of efficacy of nonviral delivery systems prevents their clinical use. Much emphasis has been placed on increasing transfection efficiency through the physiochemical modification of the PEI vectors to overcome barriers [4-7] or to exploit genes identified by gene profiling [8]; these studies have resulted in limited success and prompted investigations into identifying the mechanisms of PEI transfection. An entire new field of polymer genomics has emerged aiming to investigate the effect of polymer vectors, commonly used for drug and DNA delivery, on endogenous gene expression profiles using high-throughput techniques such as microarrays [9]. Microarray analysis has been performed to investigate the toxicogenomics of nonviral vectors used for gene delivery, including PEI [10-13]. However, in these previous studies, the objective was to treat the cells with a vector (often not complexed with DNA) to observe the associated gene expression profiles and cellular responses, in particular cytotoxicity and apoptosis [14].

Although previous studies investigated cell, transgene, DNA carrier and time dependencies on the endogenous cellular gene expression profile $[11,13,15,16]$, there was no isolation of transfected cells from untransfected cells, potentially masking information related to successful DNA transfer. Previously, we have identified gene expression profiles of an isolated transfected cell population. For those studies, HEK 293 T cells were transfected with lipoplexes delivering a plasmid encoding green fluorescent protein (GFP) gene [17]. Flow cytometric separation and microarray analysis of transgene expressing cells (GFP+) from treated but untransfected (GFP-) cell populations revealed HSPA6 and RAPIA genes as being up-regulated in GFP + cells compared to GFP- cells [17]. The activation of these genes before the delivery of lipoplexes resulted in up to 2.5-fold increased transfection [17].

In the present study, we expand our approach, extending our analysis to PEI, a widely used nonviral vector that has been shown to demonstrate in vitro $[18,19]$ and in vivo transfection $[13,20]$. In addition, PEI may transfect cells using different pathways than lipoplexes [2124], which could be expounded through microarray analysis. We used microarray analysis to identify differentially expressed genes between GFP+, GFP- and Untreated HEK 293 T cells that occur after PEI-mediated DNA delivery. Gene ontology (GO) analysis grouped these gene expression profiles into corresponding cellular processes. Furthermore, Exploratory Gene Association Network (EGAN) analysis showed interacting networks among genes and processes related to transfection. Transfection experiments, in the presence or absence of pharmacologic activators or inhibitors, further implicated the role of these genes in nonviral gene delivery and demonstrated an alternative approach to enhancing transfection through the priming of cells. With increased understanding of endogenous cellular mechanisms that occur during DNA transfer, more efficient nonviral gene delivery systems can be designed to move this technology into therapeutic applications. 


\section{Materials and methods}

\section{Cell culture and plasmid preparation}

Human embryonic epithelial kidney HEK 293 T cells (ATCC, Manassas, VA, USA) were cultured in T-75 flasks in Dulbecco's modified Eagle's medium (Gibco/Invitrogen, Carlsbad, CA, USA) containing $4.5 \mathrm{~g} / \mathrm{l}$ glucose, supplemented with $10 \%$ fetal bovine serum (Gibco), $2 \mathrm{mM} \mathrm{L-glutamine} \mathrm{(Gibco)} \mathrm{and} 100$ units/ml of penicillin (Gibco) and maintained at $37^{\circ} \mathrm{C}$ in a humidified $5 \% \mathrm{CO}_{2}$ atmosphere. For seeding, cells were dissociated at confluency with $1 \mathrm{mM}$ ethylenediaminetetraacetic acid (EDTA) and viable cells were counted using a hemocytometer and trypan blue dye exclusion assay. For all transfection experiments, plasmid pEGFPLuc, which encodes for both the enhanced green fluorescent protein (EGFP) and firefly luciferase protein under the direction of a cytomegalovirus (CMV) promoter (Clontech, Mountain View, CA, USA), was used. Plasmids were purified from bacteria culture using Qiagen (Valencia, CA, USA) reagents and stored in Tris-EDTA (TE) buffer at $-20^{\circ} \mathrm{C}$ until ready for use.

\section{Transfection optimization}

Branched 25 kDa PEI (Sigma-Aldrich, St Louis, MO, USA) was dialyzed with 10000 MWCO Slide-A-Lyzer against $\mathrm{ddH}_{2} \mathrm{O}$, lyophilized, dissolved in TE buffer at $1 \mathrm{mg} / \mathrm{ml}$ and stored at $-20{ }^{\circ} \mathrm{C}$. Polyplexes were formed in $1 \times$ Tris-buffered saline solution by dropwise addition of PEI solution to plasmid DNA (pDNA) solution, briefly vortexed for $10 \mathrm{~s}$, and incubated for $15 \mathrm{~min}$ at room temperature. Polyplexes were formed and delivered to adherent cells in serum-containing medium $18 \mathrm{~h}$ after cell seeding. Polyplexes were not removed for the duration of the study. Transfection was optimized by varying the nitrogen to phosphate ratio (N:P) and the amount of DNA and found to be optimal for high transfection and low cytotoxicity at N:P of 20 and $0.25 \mu \mathrm{g} / \mathrm{cm}^{2}$ of pDNA (Figure S1).

\section{Transfection for flow cytometry}

Cells were seeded at a density of $3.36 \times 10^{6}$ cells/flask into multiple T-75 flasks. Polyplexes were formed and delivered to adherent cells as described in transfection optimization above. Twenty-four hours after addition of polyplexes, cells were dissociated with the addition of trypsin-EDTA. Cells were pooled, counted, and concentrated between 2 and 5 million cells per $\mathrm{ml}$ in $1 \times$ phosphate-buffered-saline and placed on ice. Next, cells were sorted by fluorescence-activated cell sorting (FACS) into GFP + and GFP- populations, as described previously [17], using a B-D FACSVantage SE three-laser, high speed cell sorter (University of Nebraska-Lincoln Center for Biotechnology Flow Cytometry Core Facility) equipped with a 530/15 nm SE laser. A live gate was set on the GFP + cell population in forward scatter versus side scatter plot to remove cell debris or clumped cells from the sort. A minimum of $2 \times 10^{6}$ cells for each population was collected (GFP+, GFP- ). Untreated cells (i.e. those not treated with the polyplexes) were sorted in the same manner. Transfection experiments were performed on three different days and, after cell sorting, provided independent samples of GFP $+(n=3)$, GFP- $(n=3)$ and Untreated $(n=2)$; RNA from these eight samples was used to hybridize to microarrays (see below). 


\section{RNA extraction and quality check}

RNA extraction and quality check was performed as described previously [17]. After obtaining sorted, independent populations of transfected cells ( $\mathrm{GFP}+; n=3$ ), untransfected cells (GFP- ; $n=3$ ) and control cells (Untreated; $n=2$ ), total RNA was Trizol extracted and further purified using a RNeasy column (Qiagen) to achieve 260/280 ratio greater than 2.0 (data not shown) on Nanodrop 2000 (Thermo Scientific, West Palm Beach, FL, USA). The quality of purified RNA was assessed using a RNA 6000 Nano LabChip on an Agilent BioAnalyzer 2100 (Agilent Technologies, Santa Clara, CA, USA) and then used for microarray analysis (see below).

\section{Microarray hybridization}

Purified RNA was reverse transcribed to cDNA and hybridized to Affymetrix GeneChip Human Genome U133 Plus 2.0 Arrays (Affymetrix, Santa Clara, CA, USA) overnight at 45 ${ }^{\circ} \mathrm{C}$. After streptavidin-phycoerythrin conjugate staining, expression data were read with the GeneChip Scanner 3000 7G (Affymetrix). Affymetrix GeneChip Operating Software (GCOS, version 1.3) was used for washing, scanning and basic data analysis, including calculation of absolute values and normalization of the data with respect to internal standards. A total of eight microarrays were used: three for GFP + samples, three for GFPsamples and two for Untreated samples.

\section{Microarray analysis}

Each microarray provides 11 independent measures of gene expression $(n=11)$ for over 47 000 transcripts and variants annotated for all known genes of the human genome. Microarray expression data were background adjusted and normalized using BenjaminiHochberg statistical methods [25], and then the quality of expression data were tested using R/Bioconductor with the AffyCoreTools library package (see Table S1 and Figures S2-S7). Genes differentially expressed between GFP + and GFP-, GFP + and Untreated, and GFPand Untreated were determined using the linear models for microarrays package in R/ Bioconductor, with Benjamini-Hochberg false discovery rate (FDR) adjusted $p$-values [26]. All genes considered for further analyses (GO analysis or network analysis; see below) were 2.0-fold differentially expressed between gene profiles with FDR adjusted $p$-value less than 0.05. The gene expression data has been deposited at the NCBI Gene Expression Omnibus under accession number GSE38422.

\section{Quantitative reverse transcriptase polymerase chain reaction (qRT-PCR) validation}

Microarray data validation was performed as described previously [17]. Two-stage, singleplex qRT-PCR was used to confirm the expression of genes with greater than 5.0-fold differential expression in all gene profile comparisons with FDR adjusted $p$-values of less than 0.05 based on the microarray results. One microgram RNA was extracted from GFP + and GFP- cells and reversed transcribed to cDNA using M-MLV reverse transcriptase and random primers (Promega, Madison, WI, USA). PCR reaction mixtures were prepared using $1 \mu \mathrm{l}$ of cDNA in a $2 \times$ SYRBR Green PCR Master Mix $2 \mathrm{X}$ (Invitrogen), $2.5 \mu \mathrm{M}$ forward primer, $2.5 \mu \mathrm{M}$ reverse primer and MilliQ-water (Millipore, Billerica, MA, USA) to a final volume of $10 \mu \mathrm{l}$ per reaction. RT-PCR was performed using a two-step temperature thermal 
cycling program consisting of $15 \mathrm{~s}$ at $95^{\circ} \mathrm{C}$ and $60 \mathrm{~s}$ at $60^{\circ} \mathrm{C}$ for 40 cycles on an ABI 7300 System (Applied Biosystems, Foster City, CA, USA). GFP + and GFP- expression data were normalized using geometric averaging [27] to the endogenous controls: glyceraldehyde-3- phosphate dehydrogenase GAPD (NM_002046), hydroxymethylbilane synthase HMBS (NM_000190) and beta-2-microglobulin B2M (NM_004048). For a list of the gene-specific primers (IDT, Skokie, IL, USA) used, see the Supporting information (Table S2). Validation experiments were performed in triplicate $(n=3)$ and data are reported as the mean $\pm \mathrm{SE}$.

\section{GO bioinformatic analysis}

EGAN analysis [28] was used to find enriched GO terms, using a standard one-tailed Fisher's exact test for enrichment value less than $1 \times 10^{-5}$ considered statistically significant. Gene expression data were loaded into EGAN using the default human genome definition file for annotating probes of the microarray. Edge references and node colors were set to HG-U133 Plus 2. Background adjustment was made based on the expression level of all measured probes in the array. The raw microarray data indicating expression level, $p$ value and probe annotation number for each comparison (GFP + versus GFP-, GFP- versus Untreated, and GFP + versus Untreated) were loaded into EGAN. The summary method for mapping data was set to maximum.

\section{Gene network analysis}

The EGAN bioinformatics tool [28] was also used to explore how the 215 genes identified from the GFP + to GFP- comparison (Table S3) interact within a gene-and-pathwaynetwork, enriched (enrichment value $<0.0001$ ) to non-overlapping terms selected for correlation to transfection (e.g. 'positive regulation of cell cycle' and 'cell cycle' overlap; therefore, only the parent 'cell cycle' term was used). This type of analysis enables the visualization of genes as they interact with each other and to selected processes, ontologies, or pathways [GO, Medical Subject Headings (MeSH) and Kyoto Encyclopedia of Genes and Genomes (KEGG) databases] [29-31].

\section{Transfection in the presence or absence of pharmacologic agents}

Selected genes were further investigated for their effect on DNA transfer. These experiments were performed as described previously [17]. Briefly, transfection studies were performed in the presence and absence of pharmacological activators or inhibitors. Cells were seeded and allowed to adhere, as explained for the optimization experiments above. Pharmacologic agents were then added in concentrations and lengths of time known to activate or inhibit genes [32-40]. Polyplexes were then prepared and delivered to the treated cells or to control cells that received treatment of vehicle only. Transfection levels were assayed at $24 \mathrm{~h}$ postdelivery using a luciferase assay normalized to total protein concentration, and compared with transfection levels in vehicle-only control cells. Pharmacologic activator and inhibitors included 8CPT-2Me-cAMP [32], GGT1-298 [39], apomorphine [33], 5-aza-2'deoxycytidine [34], jasplakinolide [35], dexamethasone [36], SB203580 [40] (all from Sigma-Aldrich) and phorbol 12-myristate 13-acetate (Fisher Scientific, Pittsburgh, PA, USA) [37,38]. Statistical analysis was performed using Prism, version 5 (GraphPad, La 
Jolla, CA, USA). Comparative analyses were completed using Student's $t$-test at a 95\% confidence level. Data are reported as the mean \pm SEM.

\section{Results}

\section{Microarray data analysis}

Microarray analysis was used to compare the endogenous gene expression profiles of GFP + and GFP- populations of HEK $293 \mathrm{~T}$ cells $24 \mathrm{~h}$ after delivery of PEI polyplexes for over 45 000 genes, with 11 independent measurements of the transcriptional activity of each gene. Transfection conditions were optimized for both high transfection efficiency and low cytotoxicity (Figure S1). Comparison of GFP + gene profiles with GFP- gene profiles revealed 215 genes to be differentially expressed (Table S3) with 199 up-regulated genes and 16 down-regulated genes (Figure 1). Among these genes, nine were at least 5.0-fold differentially expressed between GFP + and GFP- gene profiles and of those, all upregulated: RAP1A, CHORDC1, ATF3, SCG5, NEB, WDR78, PGAP1, ACRC and IREB2 (Table 1). Differential comparison of GFP + with Untreated gene profiles can provide insight into potential genes involved in polyplex delivery and transgene expression, whereas comparison of GFP- and Untreated gene profiles may provide insight into 'off-target' effects of polyplex treatment that do not result in transgene expression; those results and discussion are reported in the Supporting information (Document S1).

\section{Validation of microarray transcriptional activity}

To verify microarray performance in obtaining high-throughput gene expression, qRT-PCR was used to validate microarray expression results for genes greater than 5.0-fold differentially expressed between GFP + and GFP- cells with FDR adjusted $p$-values of less than 0.05. Gene expression for RAP1A, CHORDC1, NEB, WDR78, PGAP1, ACRC, ATF3, $S C G 5$ and IREB2 was statistically up-regulated in the GFP + sample compared to GFP(Figure 2). These (qRT-PCR) results are consistent with the trend from the microarray results, although relative expression levels were discrete likely as a result of the different methods of measurement and normalization, a divergence commonly reported [41,42] and reviewed elsewhere [43-45].

\section{GO analysis}

The 215 genes differentially expressed in the GFP + versus GFP- gene profile comparison (Table S3) were further studied for enriched GO biological processes using the EGAN bioinformatics tool [28]. Of the 215 endogenous genes differentially expressed between GFP + and GFP- cells, 102 genes were associated with one or more of five parent GO processes (Table 2), including 83 genes in 'GO: 0008152 metabolic process', 50 genes in 'GO: 0050896 response to stimulus', 47 genes in 'GO: 0007049 cell cycle', 44 genes in 'GO: 0065007 biological regulation' and 31 genes in 'GO: 0071840 cellular component organization or biogenesis'. Many genes were represented in more than one of the parent GO processes (Table 2). For example, RAPIA and ATF3 genes were both found to be involved in three parent GO processes: 'metabolic process', 'response to stimulus' and 'biological regulation' (Table 2), with ATF3 additionally implicated in the 'cell cycle' GO process. Genes that appeared in this analysis and were 5.0-fold differentially expressed 
between the GFP + and GFP- comparison (Table 1) were all represented in more than one parent GO process (Table 2). Each parent GO process contained several child GO cellular processes (Table 2).

\section{Gene network and pathway analyses}

Next, the EGAN bioinformatics tool [28] was used to explore how the 215 genes from the GFP + to GFP- comparison (Table S3) interact within a gene-and-pathway-network selected specifically for terms known from literature to affect transfection [18,46-48], described here as a transfection-network. Seventy-one of the 215 genes directly or indirectly interacted with each particular process (Figure 3). For example, although RAP1A has a direct interaction with 'focal adhesion' process, it has an indirect interaction to 'cell adhesion', 'cytoskeleton organization' and 'active transport to cell nucleus' through the 'focal adhesion' process, the up-regulated ACTN2 gene and the up-regulated NEB gene (Figure 3). Of the 71 genes that were found to belong to the transfection-network, 65 genes were upregulated and six genes were down-regulated (PRAF2, MYC, BMP2, SF3A2, G6PD) (Figure 3 ), suggesting that successful DNA transfer may act primarily through up-regulation of genes rather than down-regulation. Among the nine genes identified as 5.0-fold differentially expressed from the microarray analysis comparing GFP + to GFP- gene profiles (Table 1), RAP1A, SCG5, PGAP1, ATF3 and NEB genes were discovered to have interplay among genes and processes in four key cellular processes: (i) active transport to cell nucleus; (ii) cellular response to stress; (iii) cytoskeletal signalling; and (iv) cell cycle. The remaining four most highly up-regulated genes (CHORDC1, IREB2, ACRC, WDR78) (Table 1) belonged to other GOs not enriched by this network analysis. For example, CHORDC1 belongs to 'regulation of response to stress' (GO: 0080134) and IREB2 belongs to 'regulation of translation' (GO: 0006417) [29]. ACRC and WDR78 have no known GO processes.

\section{Transfection in the presence or absence of pharmacologic agents}

To assess the usefulness of the microarray and network analyses in identifying genes as potential molecular mechanisms of DNA transfer, selected genes were evaluated for their role in DNA transfer using small-molecule activators or inhibitors (Table 3 and Figure 4) [32-40,49,50]. Activating or inhibiting RAPIA, SCG5, ACRC, ATF3, ACTA1 and IREB2 genes with pharmacologic agents resulted in altered transfection levels compared to vehicle controls. Studies that resulted in increased transfection were: activating $R A P I A(+1.7$-fold $)$, inhibiting SCG5 (+2.5-fold), activating ACRC (+1.6-fold) and activating IREB2 (+2.2-fold). Studies that resulted in decreased transfection included: activating $S C G 5$ (-1.2-fold), activating ATF3 (-2.3-fold), inhibiting ACTAI (-2.0-fold) and inhibiting IREB2 (-2.8-fold).

\section{Discussion}

Inefficient transgene expression continues to limit the efficacy of nonviral gene delivery systems in clinical applications. A lack of direct information on the endogenous gene expression profiles and intracellular signalling pathways that occur during successful DNA transfer limits the optimal design of delivery vectors. Recent studies aimed to better understand the DNA transfer process using particle tracking studies to identify putative 
barriers to DNA transfer, resulting in the common empirical approach of modifying the DNA carrier to overcome one barrier for improved efficacy [51-63]. Other studies have investigated the pharmacogenomics response of cells to the DNA carrier (alone and complexed), thereby identifying genes involved in cytotoxicity and apoptosis, offering targets for new vector design for improved safety [9-13,15,16,64]. However, even with these efforts, the molecular mediators that facilitate successful DNA transfer remain unclear [65], and the efficiency of nonviral gene delivery still remains below desired levels.

In work previously conducted in our laboratory, FACS was used to separate transfected (GFP+) cells from untransfected (GFP- ) cells, and then microarray analysis was used to obtain separate gene profiles. RAPIA and HSPA6 were found to be overexpressed in the GFP + population when compared with GFP- using lipoplex delivery [17]. Pharmacologic studies, in which the target gene was activated and a change in transfection levels determined, were used to reinforce the correlation of gene expression to the action of the encoded protein [66] in transfection. Namely, increasing endogenous levels of RAPIA and HSPA6 before treatment with lipoplexes resulted in up to 2.5 -fold increased transfection [17], thereby supporting a role for these genes as potential molecular mediators during DNA transfer. However, the number of genes reported as differentially expressed between GFP + and GFP- cells for lipoplexes [17] is in stark contrast to the research reported in the present study for polyplexes (215 genes; Table S3), providing a molecular basis of evidence that lipoplex and polyplex mechanisms of transfection may be different [11,21-24]. Even so, the two genes reported as overexpressed in GFP + cells treated with lipoplexes [17] were also overexpressed for polyplex-mediated transfection (Table S3), suggesting mechanisms that may be common during successful DNA transfer, which could be exploited in the design of new lipid- or polymer-based delivery systems. Of those two genes, RAPIA encodes for a GTPase involved in integrin-mediated cell adhesion [67], which has been correlated with transfection [68-71]. In addition, activating RAP1A before delivery of PEI complexes increased transfection levels by 1.7-fold (Table 3), similar to our previous study [17], which further implicates the importance of this gene in DNA transfer. HSPA6, heat shock 70-kDa protein 6 (HSP70B'), is stress inducible to maintain cell viability and cytoprotection [72,73]. This gene has also been shown to be involved in the nuclear import of viral particles [74] and thus could potentially be involved with the nuclear entry of nonviral DNA delivery complexes, especially those containing viral DNA promoters (e.g. CMV). The remaining identified genes in PEI-mediated transfection indicate endogenous gene expression that may be DNA carrier specific [15], potentially as a result of differences in the hydrophobicity, degradability, toxicity and routing kinetics of the complex [11,21-24].

\section{Microarray, GO and network analyses}

A combined microarray and GO analysis for GFP + compared with GFP-gene profiles provided insight into the molecular mechanisms used during PEI-mediated DNA transfer. Analyses showed that the 215 genes differentially expressed between GFP + and GFP- gene profiles (Table S3) belonged to five GOs indicating activity in: (i) cell stress (metabolic process, response to stimulus, biological regulation); (ii) the cell cycle (metabolic process, cell cycle, biological regulation); and (iii) cytoskeletal organization (metabolic process, biological regulation, cellular component organization or biosynthesis) (Table 2). Similar 
biological processes including cell stress, cell cycle and cytoskeletal organization have been previously reported to be induced by PEI polyplexes in vivo [13], and by PEI, chitosan and PAMAM polyplexes in vitro $[11,18,75]$. Our findings identify the specific genes related to those processes involved in successful DNA transfer. Network analysis revealed a coordinated induction of RAP1A, SCG5, PGAP1, ATF3 and NEB genes implicated in processes known to affect transfection (cell stress, cell cycle, and cytoskeletal processes) [18,46-48] (Figure 3 and Table 1) and indicate that these genes play a role in successful DNA transfer. Further studies involving pharmacologic activation or inhibition suggest a role for the gene in transfection for the RAPIA, SCG5 and ATF3 genes (from the network analysis) and the $A C R C, A C T A 1$ and $I R E B 2$ genes (from microarray analysis). A literature review suggests a role for these six genes in cell stress, cell cycle or cytoskeletal activity (mechanisms correlated with transfection) [76-83], as discussed below.

\section{Cell stress}

Several of the enriched GO terms indicated that genes related to cell stress activity were overexpressed in transfected cells, such as nucleic acid repair, response to DNA damage stimulus, cellular response to stress and cell cycle arrest (Table 2). Cells have a proposed set of immediate early genes that are induced in response to stress signals irrespective of cell type or nature of stressor. Godbey et al. [18] proposed two toxicities associated with polyplex treatment: immediate toxic shock to free polymer membrane destabilization and a delayed (> $8 \mathrm{~h}$ ) toxicity as a result of the cellular processing of polyplexes. The optimal transfection condition used in the present study was at an N:P of 20 (Figure S1), a condition where unbound PEI may be present, which has been shown to greatly impact transfection levels concomitant with cell stress [84-86]. The present study may identify specific genes involved in the mechanisms by which free PEI can enhance transfection by affecting cell stress, including the ATF3 gene; the up-regulation of ATF3 in GFP + cells (Table 1) indicates sustained cellular stress possibly as a result of the nondegradable nature of PEI [87]. Alternatively, $A T F 3$ may be up-regulated in response to the presence of foreign DNA because $A T F 3$ has been reported to be overexpressed immediately after viral infection [88,89]. Up-regulation of ATF3 (Table 1) suggests a common cellular response to DNA delivery systems, possibly as a cell mechanism preventing the further uptake of foreign DNA because activating ATF3 [35] in cells before the delivery of polyplexes resulted in drastically reduced transfection levels (Table 3). Taken together, gene activity that results in increased stress and DNA damage proteins or DNA repair proteins was observed in GFP + cells compared to GFP- (Tables 1 and 2; see also Supporting information, Table S3), suggesting that these genes play a role in PEI-mediated transfection.

\section{Cell cycle}

Cell cycle and cell proliferation are known to affect transfection [46,64], which is consistent with our results showing many of the parent GO terms related to the cell cycle (Table 2). Cellular stress and DNA damage often induce cell cycle checkpoints in the presence of DNA damage through sensor, transducer and effector concerted protein efforts [75]. The presence of cell cycle genes in the GFP + versus GFP- comparison appears consistent with this fact because cell stress was reported concomitant to cell cycle activity (Table 2). One gene implicated in cell growth and proliferation, and also cell stress, was the heat shock- 
inducible SCG5 gene, which was 5.3-fold up-regulated in GFP + cells (Table 1) [49,90]. $S C G 5$ is a chaperone protein required for proprotein convertase 2 (PC2), a hormone implicated in stress signalling [90]. Inhibiting SCG5 activity [33] before the delivery of complexes resulted in a 2.5 -fold increase in transfection (Table 3). Genes involved in reducing cell stress were important to transfection (above) and inhibiting the hormone signalling gene SCG5 may mask stress incurred by polyplexes, allowing for enhanced transfection. Finally, increased cell cycle activity requires increased energy levels, which is consistent with our results suggesting an increase in tricarboxylic acid (Krebs) cycle activity by up-regulation of IREB2 (Table 1) [82,83]. Increasing IREB2 activity (Table 3) [37,38] before delivery of complexes resulted in 2.2-fold increase in transfection, whereas inhibiting IREB2 decreased transfection by 2.8 -fold, confirming reports correlating cell cycle and transfection [46,64]. It should also be noted that cells were not synced to more closely mimic conditions found in vivo. In addition, data were differentially compared to eliminate intrinsic metabolic noise (e.g. basal levels of cell cycle or metabolism genes) in our gene expression analysis [91]. Taken together, these data suggest molecular mediators of the cell cycle that are important for successful PEI polyplex-mediated DNA transfer.

\section{Cytoskeletal signalling and nuclear localization}

The roles of cytoskeletal and transport processes have been strongly correlated with transfection $[47,48,71]$ and, to facilitate DNA transfer, the cytoskeletal network may be modified. In the present study, ACTA1, which is a major component of the cell cytoskeleton, was 4.46-fold up-regulated in GFP + versus GFP- gene profiles (Table S3) [92]. Inhibiting ACTA1 [36] before the delivery of complexes resulted in 2.0-fold reduced transfection (Table 3), reinforcing the important role of cytoskeletal components in DNA delivery [47,48]. Finally, the delivered DNA must localize within the nucleus, which is a critical step for transgene expression [93]. Nuclear localization signals (NLSs) can help this process and may explain the 5.95-fold up-regulation of ACRC (Table 1). ACRC gene codes for an acid repeat containing nuclear protein with a deduced nuclear localization potential because it contains eight bipartite NLSs in the C-terminal region of the protein [76,77]. This gene may facilitate nuclear localization or entry, as suggested by the 1.6-fold increase in transfection as a result of activating $A C R C$ [34] before the delivery of complexes (Table 3). The findings from the present study have identified specific genes involved in cytoskeletal signalling and nuclear localization processes that may be utilized during DNA transfer.

For nonviral gene delivery techniques to have therapeutic application, transfection efficiency and a direct understanding of the transfection process must be increased. The present study has identified genes and biological processes specific to successful DNA transfer, by analyzing gene expression profiles of transfected, untransfected and Untreated cells, separately. Subsequently, the ability of selected genes to affect transfection was confirmed by pharmacologic studies. Mediators of cell stress (DNA damage or repair proteins), the cell cycle and cytoskeletal signalling were shown to greatly influence transfection. Future studies should consider the action of the encoded proteins in these pathways as they influence DNA transfer with respect to other vectors, cell types, DNA and time points. Additionally, these genes should be considered in the design of new carriers, the 
modification of existing DNA carriers and/or in cell priming to achieve transfection levels that can advance therapeutic applications.

\section{Supplementary Material}

Refer to Web version on PubMed Central for supplementary material.

\section{Acknowledgments}

This work was supported financially by the American Heart Association (10SDG2640217); University of Nebraska Foundation (Layman Funds); Nebraska Research Initiative; and USDA CSREES-Nebraska (NEB-21-146). Flow cytometry was performed at the Flow Cytometry Core Facility (Dr Charles Kuszynski) and made possible by NIH grant number P20 RR15635 from the COBRE Program of the National Center for Research Resources. Microarray hybridization was performed at the Genomics Core Facility (Dr Yuannan Xia). Microarray analysis was performed at the Bioinformatics Core Facility (J. J. Riethoven). All facilities are part of the University of Nebraska-Lincoln Center for Biotechnology, Lincoln, NE, USA. The authors declare that there are no conflicts of interest.

\section{References}

1. Godbey WT, Wu KK, Mikos AG. Poly (ethylenimine) and its role in gene delivery. J Control Release. 1999; 60:149-160. [PubMed: 10425321]

2. Kircheis R, Wightman L, Wagner E. Design and gene delivery activity of modified polyethylenimines. Adv Drug Deliv Rev. 2001; 53:341-358. [PubMed: 11744176]

3. Schaffert D, Wagner E. Gene therapy progress and prospects: synthetic polymer-based systems. Gene Ther. 2008; 15:1131-1138. [PubMed: 18528432]

4. Blessing T, Kursa M, Holzhauser R, et al. Different strategies for formation of pegylated EGFconjugated PEI/DNA complexes for targeted gene delivery. Bioconjug Chem. 2001; 12:529-537. [PubMed: 11459457]

5. Ogris M, Steinlein P, Carotta S, et al. DNA/ polyethylenimine transfection particles: influence of ligands, polymer size, and PEGylation on internalization and gene expression. AAPS PharmSci. 2001; 3:E21. [PubMed: 11741272]

6. Liang E, Rosenblatt MN, Ajmani PS, et al. Biodegradable pH-sensitive surfactants (BPS) in liposome-mediated nucleic acid cellular uptake and distribution. Eur J Pharm Sci. 2000; 11:199_ 205. [PubMed: 11042225]

7. Duguid JG, Li C, Shi M, et al. A physicochemical approach for predicting the effectiveness of peptide-based gene delivery systems for use in plasmid-based gene therapy. Biophys J. 1998; 74:2802-2814. [PubMed: 9635734]

8. Maslanik T, Bernstein-Hanley I, Helwig B, et al. The impact of acute-stressor exposure on splenic innate immunity: a gene expression analysis. Brain Behav Immun. 2012; 26:142-149. [PubMed: 21893187]

9. Kabanov AV. Polymer genomics: an insight into pharmacology and toxicology of nanomedicines. Adv Drug Deliv Rev. 2006; 58:1597-1621. [PubMed: 17126450]

10. Omidi Y, Hollins AJ, Benboubetra M, et al. Toxicogenomics of non-viral vectors for gene therapy: a microarray study of lipofectin- and oligofectamine-induced gene expression changes in human epithelial cells. J Drug Target. 2003; 11:311-323. [PubMed: 14668052]

11. Akhtar S, Benter I. Toxicogenomics of non-viral drug delivery systems for RNAi: potential impact on siRNA-mediated gene silencing activity and specificity. Adv Drug Deliv Rev. 2007; 59:164182. [PubMed: 17481774]

12. Hollins AJ, Omidi Y, Benter IF, et al. Toxicogenomics of drug delivery systems: exploiting delivery system-induced changes in target gene expression to enhance siRNA activity. J Drug Target. 2007; 15:83-88. [PubMed: 17365277]

13. Regnstrom K, Ragnarsson EG, Fryknas M, et al. Gene expression profiles in mouse lung tissue after administration of two cationic polymers used for nonviral gene delivery. Pharm Res. 2006; 23:475-482. [PubMed: 16463010] 
14. Brazeau GA, Attia S, Poxon S, et al. In vitro myotoxicity of selected cationic macromolecules used in non-viral gene delivery. Pharm Res. 1998; 15:680-684. [PubMed: 9619774]

15. Jacobsen L, Calvin S, Lobenhofer E. Transcriptional effects of transfection: the potential for misinterpretation of gene expression data generated from transiently transfected cells.

BioTechniques. 2009; 47:617-624. [PubMed: 19594446]

16. Omidi Y, Hollins AJ, Drayton RM, et al. Polypropylenimine dendrimer-induced gene expression changes: the effect of complexation with DNA, dendrimer generation and cell type. J Drug Target. 2005; 13:431-443. [PubMed: 16308212]

17. Plautz SA, Boanca G, Riethoven JJ, et al. Microarray analysis of gene expression profiles in cells transfected with nonviral vectors. Mol Ther. 2011; 19:2144-2151.10.1038/mt.2011.161 [PubMed: 21829178]

18. Godbey WT, Wu KK, Mikos AG. Poly (ethylenimine)-mediated gene delivery affects endothelial cell function and viability. Biomaterials. 2001; 22:471-480. [PubMed: 11214758]

19. Park TG, Jeong JH, Kim SW. Current status of polymeric gene delivery systems. Adv Drug Deliv Rev. 2006; 58:467-486.10.1016/j.addr.2006.03.007 [PubMed: 16781003]

20. Wong SP, Argyros O, Howe SJ, et al. Systemic gene transfer of polyethylenimine (PEI)-plasmid DNA complexes to neonatal mice. J Control Release. 2011; 150:298-306. [PubMed: 21192993]

21. Boussif O, Lezoualc'h F, Zanta MA, et al. A versatile vector for gene and oligonucleotide transfer into cells in culture and in vivo: polyethylenimine. Proc Natl Acad Sci USA. 1995; 92:7297-7301. [PubMed: 7638184]

22. Zelphati O, Szoka FC Jr. Mechanism of oligonucleotide release from cationic liposomes. Proc Natl Acad Sci USA. 1996; 93:11493-11498. [PubMed: 8876163]

23. Xu Y, Szoka FC Jr. Mechanism of DNA release from cationic liposome/DNA complexes used in cell transfection. Biochemistry. 1996; 35:5616-5623. [PubMed: 8639519]

24. Tachibana R, Ide N, Shinohara Y, et al. An assessment of relative transcriptional availability from nonviral vectors. Int J Pharm. 2004; 270:315-321. [PubMed: 14726146]

25. Wu ZJ, Irizarry RA, Gentleman R, et al. A model-based background adjustment for oligonucleotide expression arrays. J Am Stat Assoc. 2004; 99:909-

917.10.1198/016214504000000683

26. Benjamini Y, Hochberg Y. Controlling the false discovery rate - a practical and powerful approach to multiple testing. J Roy Stat Soc B. 1995; 57:289-300.

27. Vandesompele J, De Preter K, Pattyn F, et al. Accurate normalization of real-time quantitative RTPCR data by geometric averaging of multiple internal control genes. Genome Biol. 2002; 3:RESEARCH0034. [PubMed: 12184808]

28. Paquette J, Tokuyasu T. EGAN: exploratory gene association networks. Bioinformatics. 2010; 26:285-286. [PubMed: 19933825]

29. Ashburner M, Ball CA, Blake JA, et al. Gene ontology: tool for the unification of biology. The Gene Ontology Consortium. Nat Genet. 2000; 25:25-29. [PubMed: 10802651]

30. Kanehisa M, Goto S, Kawashima S, et al. The KEGG resource for deciphering the genome. Nucleic Acids Res. 2004; 32:D277-280. [PubMed: 14681412]

31. Rogers FB. Medical subject headings. Bull Med Libr Assoc. 1963; 51:114-116. [PubMed: 13982385]

32. Enserink JM, Christensen AE, de Rooij J, et al. A novel Epac-specific cAMP analogue demonstrates independent regulation of Rap1 and ERK. Nat Cell Biol. 2002; 4:901-906. [PubMed: 12402047]

33. Van Horssen AM, Van Kuppeveld FJ, Martens GJ. Manipulation of disulfide bonds differentially affects the intracellular transport, sorting, and processing of neuroendocrine secretory proteins. J Neurochem. 1998; 71:402-409. [PubMed: 9648890]

34. Weil R, Galindo CL, Garner HR. Engineering in genomics - a high-resolution survey of the effects of 5-aza-dC treatment on the chromatin state of MCF7 breast cancer cells. IEEE Eng Med Biol. 2008; 27:86-100.

35. Chen BP, Wolfgang CD, Hai T. Analysis of ATF3, a transcription factor induced by physiological stresses and modulated by gadd153/Chop10. Mol Cell Biol. 1996; 16:1157-1168. [PubMed: 8622660] 
36. Wei L, Wang L, Carson JA, et al. Beta1 integrin and organized actin filaments facilitate cardiomyocyte-specific RhoA-dependent activation of the skeletal alpha-actin promoter. FASEB J. 2001; 15:785-796. [PubMed: 11259397]

37. Iwai K, Klausner RD, Rouault TA. Requirements for iron-regulated degradation of the RNA binding protein, iron regulatory protein 2. EMBO J. 1995; 14:5350-5357. [PubMed: 7489724]

38. Samaniego F, Chin J, Iwai K, et al. Molecular characterization of a second iron-responsive element binding protein, iron regulatory protein 2 . Structure, function, and post-translational regulation. J Biol Chem. 1994; 269:30904-30910. [PubMed: 7983023]

39. Hecquet C, Lefevre G, Valtink M, et al. cAMP inhibits the proliferation of retinal pigmented epithelial cells through the inhibition of ERK1/2 in a PKA-independent manner. Oncogene. 2002; 21:6101-6112. [PubMed: 12203122]

40. Lu D, Chen J, Hai T. The regulation of ATF3 gene expression by mitogen-activated protein kinases. Biochem J. 2007; 401:559-567. [PubMed: 17014422]

41. Lee $\mathrm{CH}$, Subramanian S, Beck AH, et al. MicroRNA profiling of BRCA1/ 2 mutation-carrying and non-mutation-carrying high-grade serous carcinomas of ovary. PloS One. 2009; 4:e7314. [PubMed: 19798417]

42. Lim W, Kwan JL, Goh LK, et al. Evaluation of gene expression profiles and pathways underlying postnatal development in mouse sclera. Mol Vis. 2012; 18:1436-1448. [PubMed: 22736935]

43. Chuaqui RF, Bonner RF, Best CJ, et al. Post-analysis follow-up and validation of microarray experiments. Nat Genet. 2002; 32(Suppl):509-514. [PubMed: 12454646]

44. Etienne W, Meyer MH, Peppers J, et al. Comparison of mRNA gene expression by RT-PCR and DNA microarray. BioTechniques. 2004; 36:618-620. 622, 624-616. [PubMed: 15088380]

45. Morey JS, Ryan JC, Van Dolah FM. Microarray validation: factors influencing correlation between oligonucleo-tide microarrays and real-time PCR. Biol Proced Online. 2006; 8:175-193. [PubMed: 17242735]

46. Brunner S, Sauer T, Carotta S, et al. Cell cycle dependence of gene transfer by lipoplex, polyplex and recombinant adenovirus. Gene Ther. 2000; 7:401-407. [PubMed: 10694822]

47. Dinh AT, Pangarkar C, Theofanous T, et al. Understanding intracellular transport processes pertinent to synthetic gene delivery via stochastic simulations and sensitivity analyses. Biophys J. 2007; 92:831-846. [PubMed: 17085500]

48. Grosse S, Aron Y, Thevenot G, et al. Cytoskeletal involvement in the cellular trafficking of plasmid/PEI derivative complexes. J Control Release. 2007; 122:111-117. [PubMed: 17658650]

49. Braks JA, Broers CA, Danger JM, et al. Structural organization of the gene encoding the neuroendocrine chaperone 7B2. Eur J Biochem. 1996; 236:60-67. [PubMed: 8617287]

50. Schalinske KL, Eisenstein RS. Phosphor-ylation and activation of both iron regulatory proteins 1 and 2 in HL-60 cells. J Biol Chem. 1996; 271:7168-7176. [PubMed: 8636154]

51. Hashimoto M, Morimoto M, Saimoto H, et al. Lactosylated chitosan for DNA delivery into hepatocytes: the effect of lactosylation on the physicochemical properties and intracellular trafficking of pDNA/chitosan complexes. Bioconjug Chem. 2006; 17:309-316. [PubMed: 16536460]

52. Iida T, Mori T, Katayama Y, et al. Overall interaction of cytosolic proteins with the PEI/DNA complex. J Control Release. 2007; 118:364-369. [PubMed: 17292504]

53. Oh YK, Suh D, Kim JM, et al. Polyethylenimine-mediated cellular uptake, nucleus trafficking and expression of cytokine plasmid DNA. Gene Ther. 2002; 9:1627-1632. [PubMed: 12424615]

54. Suh J, Wirtz D, Hanes J. Efficient active transport of gene nanocarriers to the cell nucleus. Proc Natl Acad Sci USA. 2003; 100:3878-3882.10.1073/pnas.0636277100 [PubMed: 12644705]

55. Segura T, Shea LD. Materials for non-viral gene delivery. Annu Rev Mater Res. 2001; 31:25-46.

56. Nishikawa M, Huang L. Nonviral vectors in the new millennium: delivery barriers in gene transfer. Hum Gene Ther. 2001; 12:861-870. [PubMed: 11387052]

57. Muller OJ, Katus HA, Bekeredjian R. Targeting the heart with gene therapy-optimized gene delivery methods. Cardiovasc Res. 2007; 73:453-462. [PubMed: 17097076]

58. Hagstrom JE. Self-assembling complexes for in vivo gene delivery. Curr Opin Mol Ther. 2000; 2:143-149. [PubMed: 11249634] 
59. Azzam T, Domb AJ. Current developments in gene transfection agents. Curr Drug Deliv. 2004; 1:165-193. [PubMed: 16305382]

60. Baker AH. Designing gene delivery vectors for cardiovascular gene therapy. Prog Biophys Mol Biol. 2004; 84:279-299.10.1016/j.pbiomolbio.2003.11.006 [PubMed: 14769440]

61. Wiethoff CM, Middaugh CR. Barriers to nonviral gene delivery. J Pharm Sci. 2003; 92:203-217. [PubMed: 12532370]

62. Medina-Kauwe LK, Xie J, Hamm-Alvarez S. Intracellular trafficking of nonviral vectors. Gene Ther. 2005; 12:1734-1751. [PubMed: 16079885]

63. Khalil IA, Kogure K, Akita H, et al. Uptake pathways and subsequent intracellular trafficking in nonviral gene delivery. Pharmacol Rev. 2006; 58:32-45. [PubMed: 16507881]

64. Hakamada K, Miyake J. Evaluation method for gene transfection by using the period of onset of gene expression and cell division. J Biosci Bioeng. 2012; 113:124-127. [PubMed: 22019412]

65. Lai SK, Hida K, Chen C, et al. Characterization of the intracellular dynamics of a non-degradative pathway accessed by polymer nanoparticles. J Control Release. 2008; 125:107-111. [PubMed: 18053606]

66. Gry M, Rimini R, Stromberg S, et al. Correlations between RNA and protein expression profiles in 23 human cell lines. BMC Genomics. 2009; 10:365.10.1186/1471-2164-10-365 [PubMed: 19660143]

67. Bos JL, de Rooij J, Reedquist KA. Rap1 signalling: adhering to new models. Nat Rev Mol Cell Biol. 2001; 2:369-377. [PubMed: 11331911]

68. Hattori Y, Maitani Y. DNA/Lipid complex incorporated with fibronectin to cell adhesion enhances transfection efficiency in prostate cancer cells and xenografts. Biol Pharm Bull. 2007; 30:603-607. [PubMed: 17329867]

69. Chowdhury EH, Nagaoka M, Ogiwara K, et al. Integrin-supported fast rate intracellular delivery of plasmid DNA by extracellular matrix protein embedded calcium phosphate complexes. Biochemistry. 2005; 44:12273-12278. [PubMed: 16156640]

70. Kong HJ, Hsiong S, Mooney DJ. Nanoscale cell adhesion ligand presentation regulates nonviral gene delivery and expression. Nano Lett. 2007; 7:161-166. [PubMed: 17212457]

71. Kasputis T, Pannier AK. The role of surface chemistry-induced cell characteristics on nonviral gene delivery to mouse fibroblasts. J Biol Eng. 2012; 6:17. [PubMed: 22967455]

72. Noonan EJ, Place RF, Giardina C, et al. Hsp70B' regulation and function. Cell Stress Chaperones. 2007; 12:219-229. [PubMed: 17915554]

73. Noonan E, Giardina C, Hightower L. Hsp70B' and Hsp72 form a complex in stressed human colon cells and each contributes to cytoprotection. Experimental cell research. 2008; 314:2468-2476. [PubMed: 18579131]

74. Agostini I, Popov S, Li J, et al. Heat-shock protein 70 can replace viral protein R of HIV-1 during nuclear import of the viral preintegration complex. Exp Cell Res. 2000; 259:398-403. [PubMed: 10964507]

75. Schweikl H, Hiller KA, Eckhardt A, et al. Differential gene expression involved in oxidative stress response caused by triethylene glycol dimethacrylate. Biomaterials. 2008; 29:1377-1387. [PubMed: 18164055]

76. Rochman M, Postnikov Y, Correll S, et al. The interaction of NSBP1/HMGN5 with nucleosomes in euchromatin counteracts linker histone-mediated chromatin compaction and modulates transcription. Mol Cell. 2009; 35:642-656. [PubMed: 19748358]

77. Nolte D, Ramser J, Niemann S, et al. ACRC codes for a novel nuclear protein with unusual acidic repeat tract and maps to DYT3 (dystonia parkinsonism) critical interval in xq13. 1. Neurogenetics. 2001; 3:207-213. [PubMed: 11714101]

78. Simons K, Toomre D. Lipid rafts and signal transduction. Nat Rev Mol Cell Biol. 2000; 1:31-39. [PubMed: 11413487]

79. Maeda Y, Tashima Y, Houjou T, et al. Fatty acid remodelling of GPI-anchored proteins is required for their raft association. Mol Biol Cell. 2007; 18:1497-1506. [PubMed: 17314402]

80. Tanaka S, Maeda Y, Tashima Y, et al. Inositol deacylation of glycosylphosphatidylinositolanchored proteins is mediated by mammalian PGAP1 and yeast Bst1p. J Biol Chem. 2004; 279:14256-14263. [PubMed: 14734546] 
81. Michowski W, Ferretti R, Wisniewska MB, et al. Morgana/CHP-1 is a novel chaperone able to protect cells from stress. Biochim Biophys Acta. 1803; 2010:1043-1049.

82. Testa U, Petrini M, Quaranta MT, et al. Iron up-modulates the expression of transferrin receptors during monocyte-macrophage maturation. J Biol Chem. 1989; 264:13181-13187. [PubMed: 2473988]

83. Hanson ES, Leibold EA. Regulation of iron regulatory protein 1 during hypoxia and hypoxia/ reoxygenation. J Biol Chem. 1998; 273:7588-7593. [PubMed: 9516462]

84. Dai Z, Gjetting T, Mattebjerg MA, et al. Elucidating the interplay between DNA-condensing and free polycations in gene transfection through a mechanistic study of linear and branched PEI. Biomaterials. 2011; 32:8626-8634. [PubMed: 21862120]

85. Yue Y, Jin F, Deng R, et al. Revisit complexation between DNA and polyethylenimine - effect of length of free polycationic chains on gene transfection. J Control Release. 2011a; 152:143-151. [PubMed: 21457737]

86. Yue Y, Jin F, Deng R, et al. Revisit complexation between DNA and polyethylenimine -effect of uncomplexed chains free in the solution mixture on gene transfection. J Control Release. 2011b; 155:67-76. [PubMed: 21056067]

87. Lv H, Zhang S, Wang B, et al. Toxicity of cationic lipids and cationic polymers in gene delivery. J Control Release. 2006; 114:100-109. [PubMed: 16831482]

88. Wolfgang CD, Chen BP, Martindale JL, et al. gadd153/Chop10, a potential target gene of the transcriptional repressor ATF3. Mol Cell Biol. 1997; 17:6700-6707. [PubMed: 9343434]

89. Granberg F, Svensson C, Pettersson U, et al. Adenovirus-induced alterations in host cell gene expression prior to the onset of viral gene expression. Virology. 2006; 353:1-5. [PubMed: 16860366]

90. Mbikay M, Seidah NG, Chretien M. Neuroendocrine secretory protein 7B2: structure, expression and functions. Biochem J. 2001; 357:329-342. [PubMed: 11439082]

91. Raser JM, O’Shea EK. Control of stochasticity in eukaryotic gene expression. Science. 2004; 304:1811-1814. [PubMed: 15166317]

92. Geiger RC, Taylor W, Glucksberg MR, et al. Cyclic stretch-induced reorganization of the cytoskeleton and its role in enhanced gene transfer. Gene Ther. 2006; 13:725-731. [PubMed: 16437132]

93. Miller AM, Dean DA. Tissue-specific and transcription factor-mediated nuclear entry of DNA. Adv Drug Deliv Rev. 2009; 61:603-613. [PubMed: 19393704]

94. Bhattacharyya S, Sargent JL, Du P, et al. Egr-1 induces a profibrotic injury/repair gene program associated with systemic sclerosis. PloS One. 2011; 6:e23082.10.1371/journal.pone.0023082 [PubMed: 21931594]

95. Panaviene Z, Moncman CL. Linker region of nebulin family members plays an important role in targeting these molecules to cellular structures. Cell Tissue Res. 2007; 327:353-369. [PubMed: 17177073]

96. Drake DM, Pack DW. Biochemical investigation of active intracellular transport of polymeric gene-delivery vectors. J Pharm Sci. 2008; 97:1399-1413. [PubMed: 17712850]

97. Zhu N, Shao Y, Xu L, et al. Gadd45-alpha and Gadd45-gamma utilize p38 and JNK signaling pathways to induce cell cycle G2/M arrest in Hep-G2 hepatoma cells. Mol Biol Rep. 2009; 36:2075-2085. [PubMed: 19048389]

98. Natori S, Iguchi H, Ohashi M, et al. Thyrotropin releasing hormone (TRH)-induced release of 7B2 (neuroendocrine polypeptide) in vivo and in vitro using adenoma cells of a patient with acromegaly. Jpn J Med. 1991; 30:208-212. [PubMed: 1920959]

99. Hwang JR, Lindberg I. Inactivation of the 7B2 inhibitory CT peptide depends on a functional furin cleavage site. J Neurochem. 2001; 79:437-444. [PubMed: 11677272] 


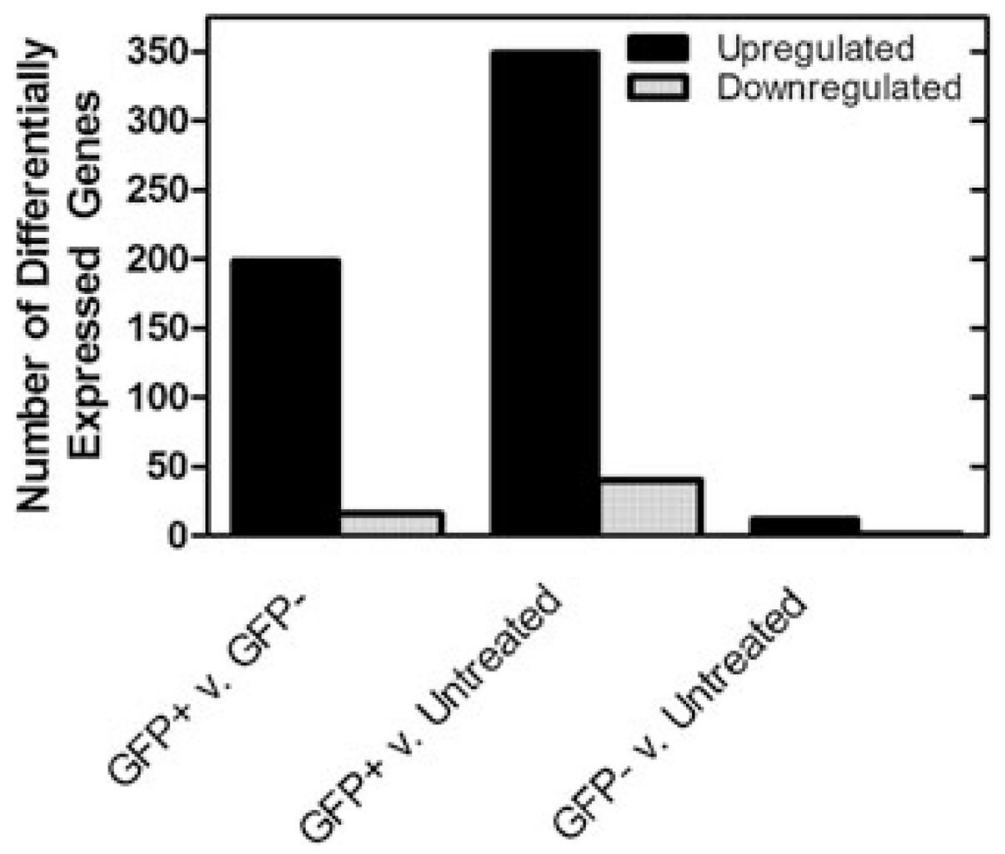

Figure 1.

The number of genes differentially expressed for transfected (GFP+), untransfected (GFP- ) or Untreated cell comparisons $24 \mathrm{~h}$ after delivery of polyplexes to HEK $293 \mathrm{~T}$ cells.

Summary data represent up-regulated (black bars) or down-regulated (grey bars) genes with differential expression greater than 2.0-fold with significance $(p<0.05)$ from hybridization experiments using human cDNA microarrays containing over 45000 probes. Untreated cells were not treated with polyplexes. 


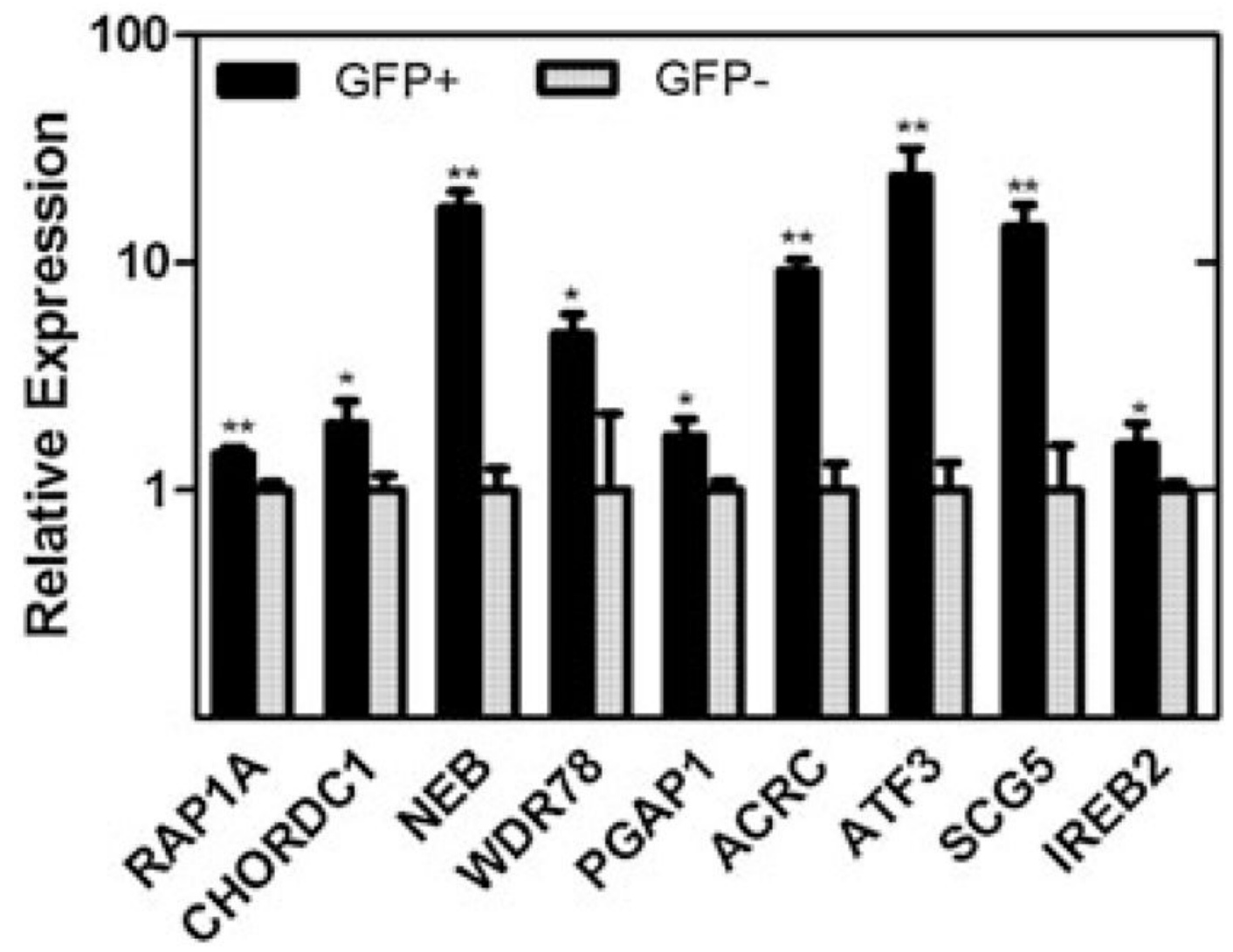

Figure 2.

Quantitative RT-PCR reactions confirm gene changes measured by the microarrays for transfected (GFP+) samples (black bars) and untransfected (GFP- ) samples (grey bars). GFP + and GFP- expression was normalized to endogenous housekeeping controls (see Materials and methods) to provide relative expression of each measured gene. Data are reported as the mean \pm SEM $(n=3)$ and significant changes between GFP + and GFPexpression are indicated by asterisks $(* p<0.05$ or $* * p<0.01)$. 


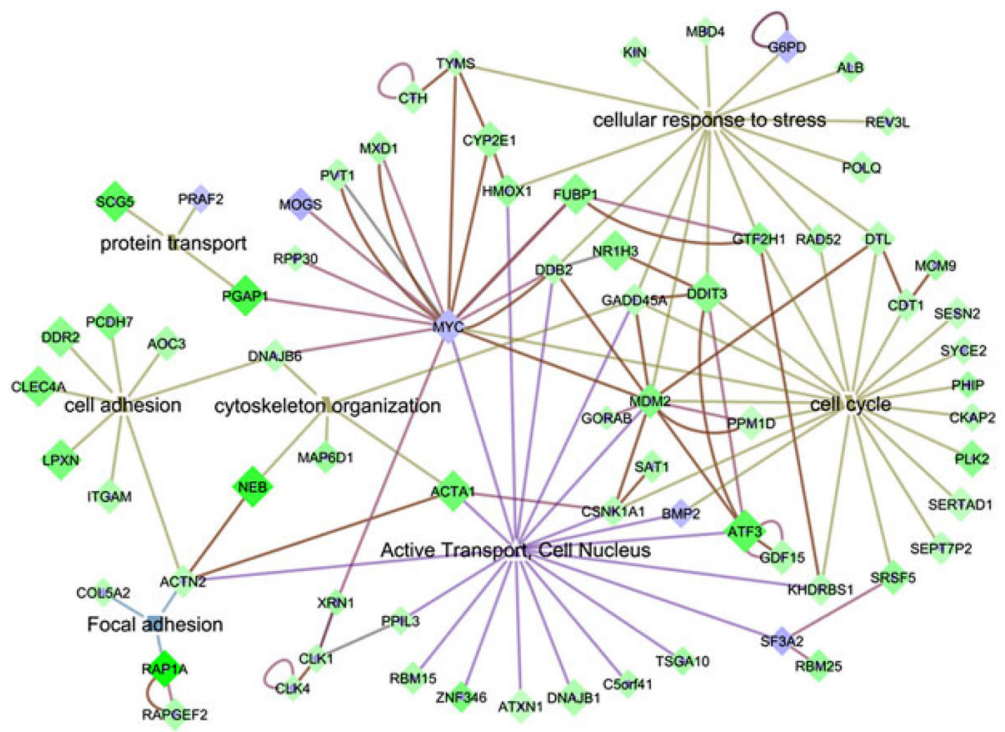

Figure 3.

Multiple processes and pathways were identified by EGAN linking genes (differentially expressed between transfected cells (GFP+) and untransfected (GFP- ) cells $24 \mathrm{~h}$ after treatment with polyplexes) to processes known to affect transfection. These linkages represent association of genes with GO, MESH and KEGG terms found to be highly enriched. Processes or pathways can be seen to be specifically up-regulated or downregulated by genes in green or blue, respectively. All line colors, node sizes and node colors are default settings of EGAN for the type of interaction, significance and relative expression [28]. 

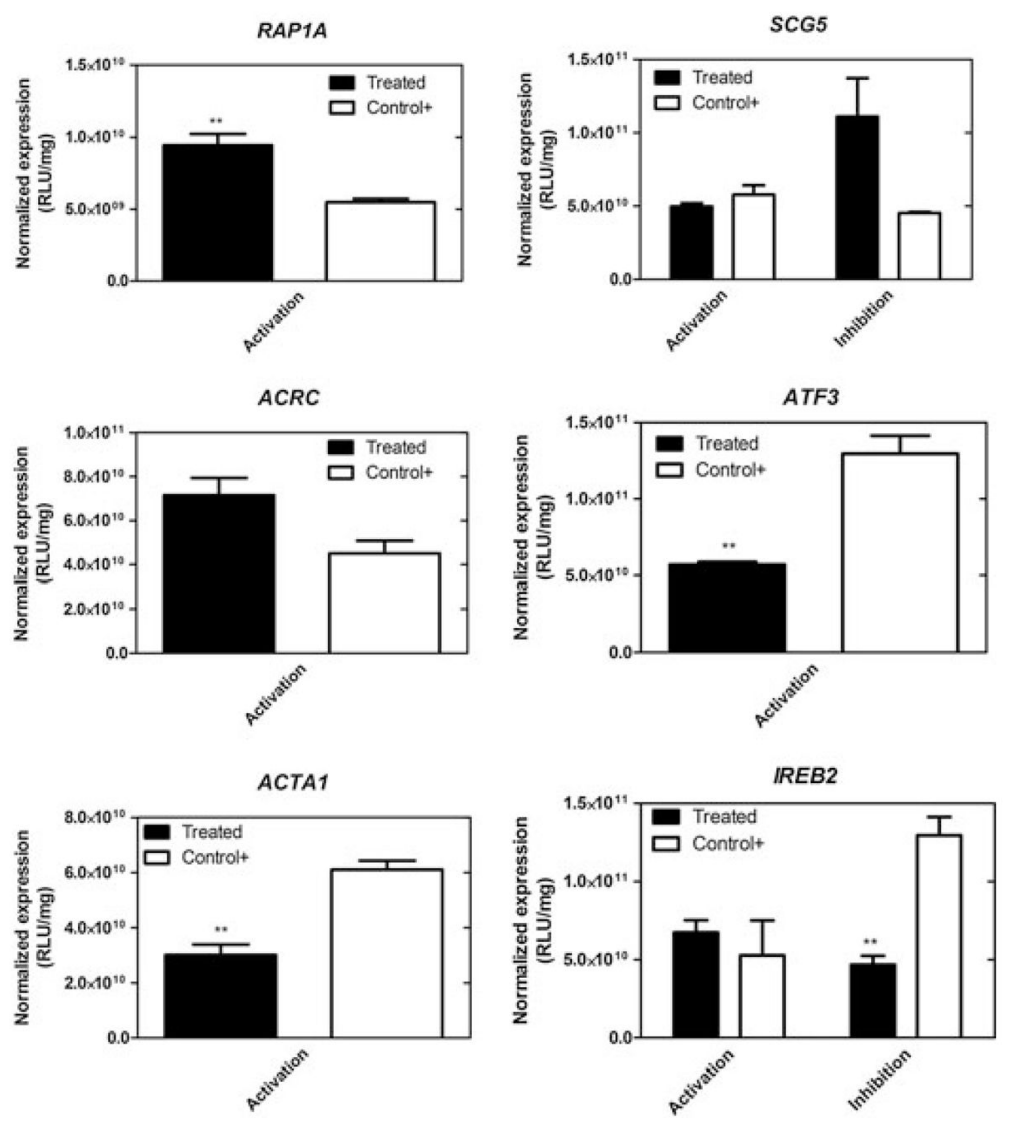

Figure 4.

HEK 293 T cells were treated with pharmacologic agent (Treated; black bars) or treated only with the vehicle used to deliver the pharmacologic agent (Control+; open bars) to activate or inhibit RAP1A, SCG5, ACRC, ATF3, ACTA1 or IREB2 genes (for conditions, see Table 3). Polyplexes were then delivered and transfection levels were assayed (see Materials and methods) after $24 \mathrm{~h}$. Data are reported as the mean $\pm \operatorname{SEM}(n=3)$ and significant changes between treated and vehicle-only transfection levels are indicated by asterisks $(* * p$ $<0.01)$. 


\section{Table 1}

Genes greater than 5.0-fold differentially expressed in the GFP + versus GFP- gene profile comparison

\begin{tabular}{|c|c|c|c|}
\hline Gene name & Gene role & Differential expression & $p$-value ${ }^{a}$ \\
\hline$R A P 1 A$ & $\begin{array}{l}\text { Encodes for a GTPase implicated in integrin-mediated cell adhesion and focal } \\
\text { adhesions [94] }\end{array}$ & 12.58 & $1.23 \times 10^{4}$ \\
\hline CHORDC1 & $\begin{array}{l}\text { Cysteine and histidine-rich domain (CHORD) containing } 1 \text { encodes for the heat shock } \\
\text { inducible Morgana/CHP-1 protein [82] }\end{array}$ & 10.38 & $8.15 \times 10^{6}$ \\
\hline$N E B$ & $\begin{array}{l}\text { Nebulin has several domains that may play essential roles in cell migration, motility, } \\
\text { cytoskeletal dynamics, and focal adhesions }[95,96]\end{array}$ & 7.81 & $1.13 \times 10^{5}$ \\
\hline$W D R 78$ & Encodes for the WD repeat domain 78 protein with high lipid raft affinity [79] & 6.96 & $1.84 \times 10^{5}$ \\
\hline$P G A P 1$ & $\begin{array}{l}\text { Responsible for anchoring the glycolipid GPI (glycosylphosphatidylinositol) to proteins } \\
\text { which are then transported and anchored at the cell membrane, especially within lipid } \\
\text { rafts }[80,81]\end{array}$ & 6.33 & $8.52 \times 10^{4}$ \\
\hline$A C R C$ & Contains 8 bipartite NLSs and is found to localize with chromatin [77] & 5.95 & $6.36 \times 10^{4}$ \\
\hline$A T F 3$ & $\begin{array}{l}\text { Activating transcription factor } 3 \text {, is an immediate-early gene that acts as a repressor of } \\
\text { ATF promoter sites and is inducible through the NF-kB and JNK/SAPK signal } \\
\text { transduction pathway }[35,89,97]\end{array}$ & 5.34 & $2.44 \times 10^{4}$ \\
\hline SCG5 & $\begin{array}{l}\text { Secretogranin V ( } 7 \mathrm{~B} 2 \text { protein) encodes for the stress inducible sorting chaperone that } \\
\text { activates prohormone convertase PC } 2 \text { carboxy terminated protease activity upon } \\
\text { binding }[49,91,98,99]\end{array}$ & 5.30 & $1.13 \times 10^{5}$ \\
\hline IREB2 & $\begin{array}{l}\text { Iron-responsive element binding protein } 2 \text { is activated in response to oxidative stress } \\
\text { and energy metabolism }[83,84]\end{array}$ & 5.30 & $2.44 \times 10^{4}$ \\
\hline
\end{tabular}

${ }^{a}$ Adjusted for FDR. 
Table 2

Statistically over-represented GO terms for GFP + versus GFP- gene profile comparison

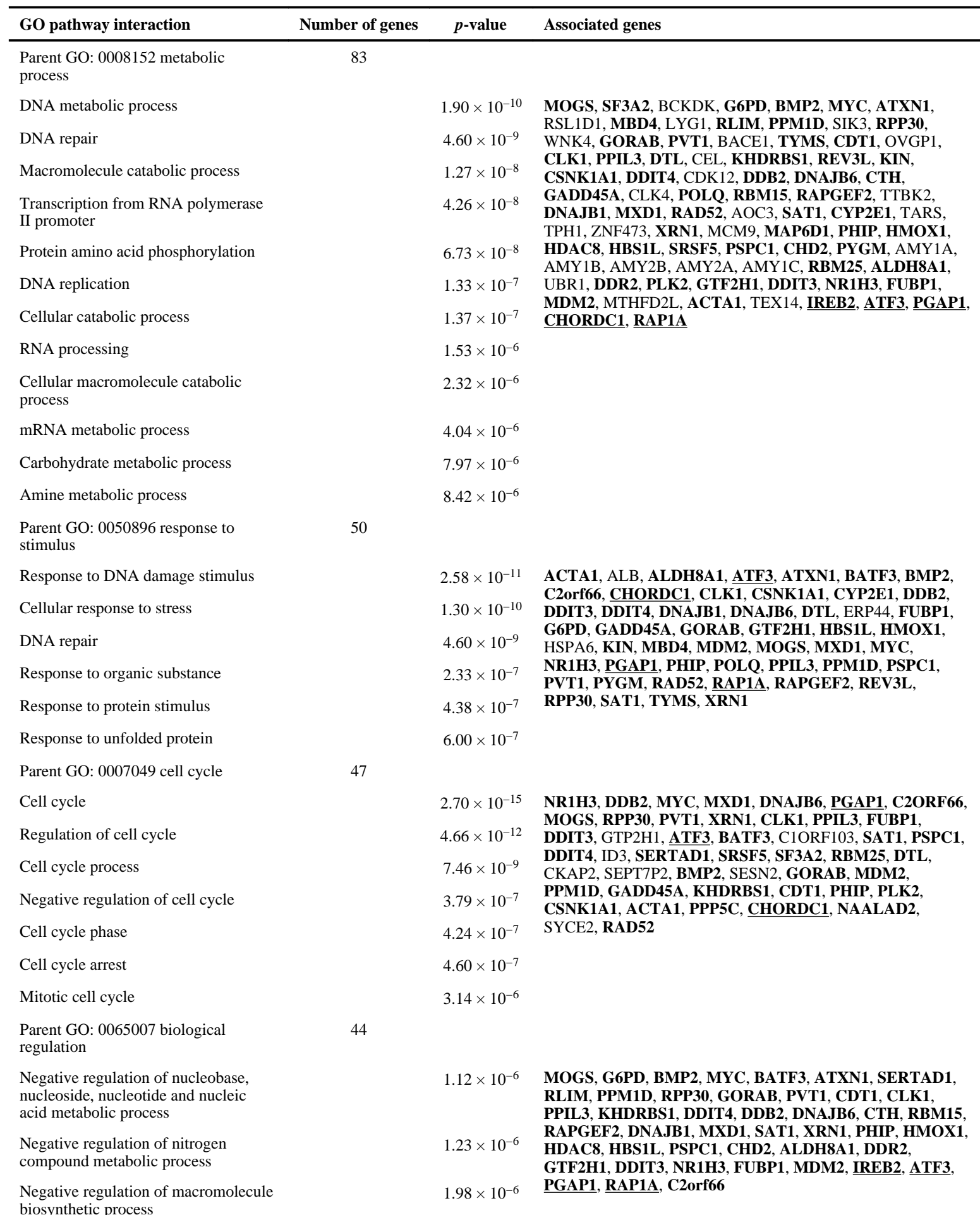




\begin{tabular}{|c|c|c|c|}
\hline GO pathway interaction & Number of genes & $p$-value & Associated genes \\
\hline $\begin{array}{l}\text { Regulation of transcription from RNA } \\
\text { polymerase II promoter }\end{array}$ & & $2.10 \times 10^{-6}$ & \\
\hline $\begin{array}{l}\text { Negative regulation of cellular } \\
\text { biosynthetic process }\end{array}$ & & $2.58 \times 10^{-6}$ & \\
\hline $\begin{array}{l}\text { Negative regulation of biosynthetic } \\
\text { process }\end{array}$ & & $2.98 \times 10^{-6}$ & \\
\hline $\begin{array}{l}\text { Negative regulation of cellular } \\
\text { metabolic process }\end{array}$ & & $3.54 \times 10^{-6}$ & \\
\hline Negative regulation of transcription & & $3.58 \times 10^{-6}$ & \\
\hline $\begin{array}{l}\text { Negative regulation of macromolecule } \\
\text { metabolic process }\end{array}$ & & $4.33 \times 10^{-6}$ & \\
\hline $\begin{array}{l}\text { Negative regulation of metabolic } \\
\text { process }\end{array}$ & & $8.69 \times 10^{-6}$ & \\
\hline Negative regulation of gene expression & & $8.69 \times 10^{-6}$ & \\
\hline $\begin{array}{l}\text { Parent GO: } 0071840 \text { cellular } \\
\text { component organization or biogenesis }\end{array}$ & 31 & & \\
\hline $\begin{array}{l}\text { Macromolecular complex subunit } \\
\text { organization }\end{array}$ & & $8.17 \times 10^{-7}$ & $\begin{array}{l}\text { PPIL3, CLK1, XRN1, MYC, RPP30, MOGS, PGAP1, } \\
\text { C2ORF66, DDB2, NR1H3, MXD1, DNAJB6, PVT1, FUBP1, }\end{array}$ \\
\hline Macromolecular complex assembly & & $2.30 \times 10^{-6}$ & $\begin{array}{l}\text { GTF2H1, PPP5C, CHORDC1, NAALAD2, HMOX1, LPXN, } \\
\text { HIST1H2BD, SRSF5, MAP6D1, SF3A2, RBM25, ATL2, } \\
\text { ACTN2, CTH, MDM2, PPM1D, GORAB }\end{array}$ \\
\hline
\end{tabular}

Number of genes associated with each parent GO process are shown. Associated genes are shown in bold if they are repeated in more than one parent GO processes and underlined if differential expression is greater than 5.0-fold. 


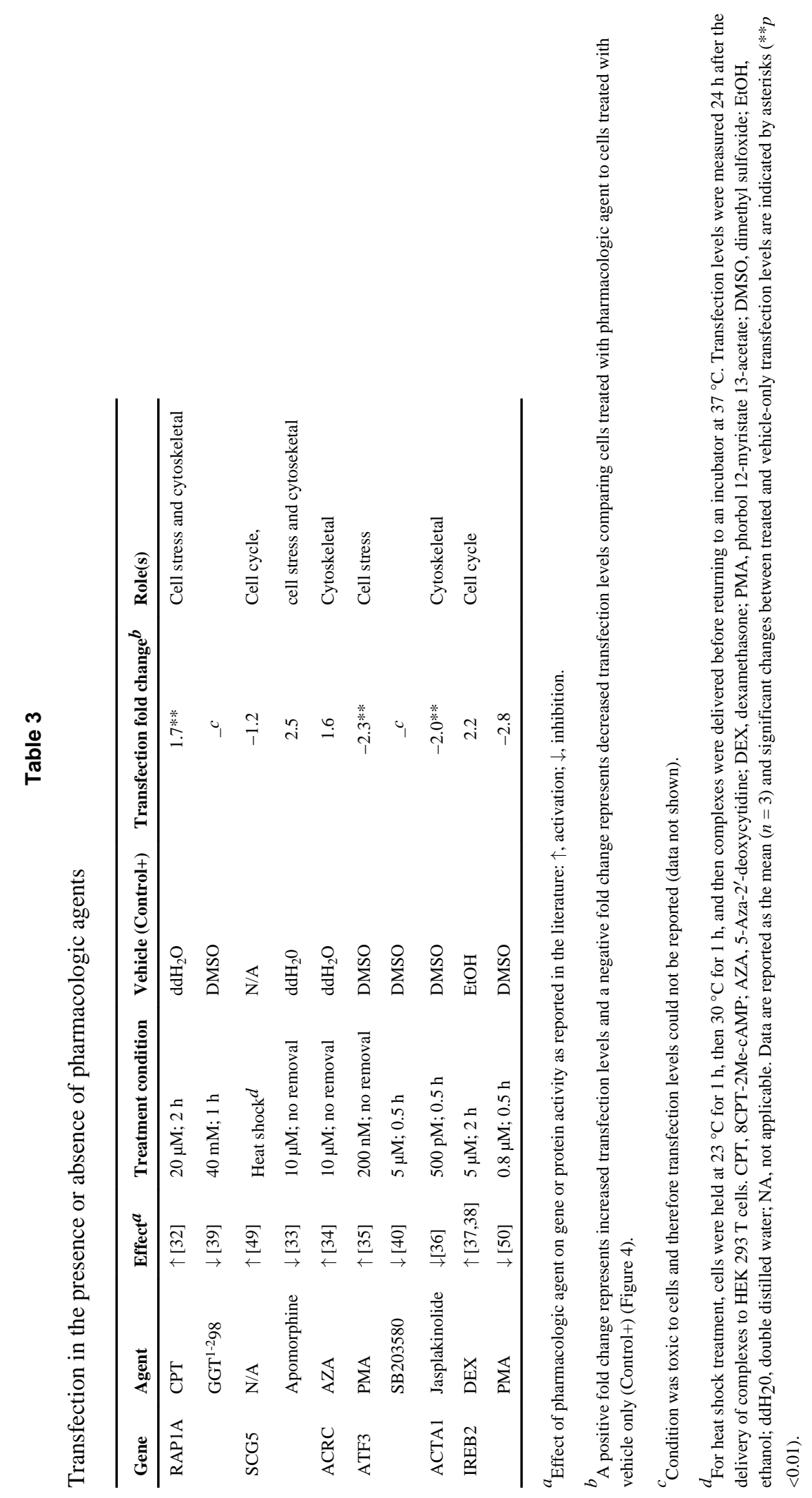

J Gene Med. Author manuscript; available in PMC 2014 July 30. 